\title{
GENETIC, PHENOTYPIC AND ENVIRONMENTAL VARIANCES AND CHARACTER ASSOCIATIONS IN KENAF
}

\author{
C. A. ECHEKWU and F.A. SHOWEMIMO \\ Institute for Agricultural Research, Ahmadu Bello University, P.M.B 1044, Samaru, Zaria, Nigeria
}

(Received 20 June, 2001; accepted 10 May, 2004)

\begin{abstract}
Kenaf (Hibiscus cannabinus L.) is an important food and livestock feed in Nigeria, which has hitherto been ignored in genetic improvement. Data obtained from evaluating fifty-seven diverse genotypes of Kenaf for two years in Samaru in the Nigerian Guinea Savanna ecological zone were used to study genetic variability and interrelationships between seed yield and its components. The results indicate a preponderance of genetic components of variance for seed yield, plant height, number of seeds per pod and 1000 seed weight indicating that selection for these traits should result in heritable improvements. Seed yield was found to be positively and significantly correlated with plant height, number of seeds per pod and 1000 seed weight. Significant and positive correlations were also obtained between plant height and number of capsules per plant and between 1000 seed weight and number of seeds per pod. The path-coefficient analysis indicates that number of seeds per pod and 1000 seed weight had the highest direct effects on seed yield. It is suggested that for a meaningful seed yield improvement programme, efforts should be directed towards the best balance between number of seeds per pod and 1000 seed weight.
\end{abstract}

Key Words: Hibiscus cannabinus, Nigeria, path-coefficient analysis

\section{RÉSUMÉ}

Kenaf (Hibicus cannabinus L.) est une importante nourriture et un aliment pour les animaux au Nigeria, qui a été littéralement ignoré dans l'amélioration génétique. Les données récoltées durant l'évaluation de cinquante sept diverses gênes de Kenaf pour deux ans en Samaru dans la zone écologique de la savane guinéenne du Nigeria étaient utilises pour étudier la variation génétique et l'interrelation entre le rendement en graines et ses composantes. Les résultats indiquent une prépondérance des composantes génétiques dans la variance du rendement en graines, la taille de la plante, nombre de graines par gousse et le poids de 1000 graines indiquant une sélection pour ces races conduirait à une amélioration de l'héritage. Le rendement en grains était positivement et significativement corrélé avec la taille de la plante et le nombre des capsules par plante et le poids de 1000 graines, et nombre de graines par gousse. L'analyse des coefficients des corrélations indique que le nombre de graines par gousse et le poids de 1000 graines avaient l'effet direct le plus élevé sur le rendement en graines. Il est recommandé que des efforts soient orientés vers l'équilibre entre le nombre des graines par gousse et le poids de 1000 graines, pour que l'impact du programme d'amélioration de rendement soit significatif.

Mots Clés: Hibicus cannabinus, Nigeria, analyse des coefficients de corrélations 


\section{INTRODUCTION}

Kenaf (Hibiscus cannabinus L.) is cultivated widely in the tropics as a fibre plant and is used as a jute substitute in the manufacture of sacs, twines, carpets and other products. The leaves and flowers are used as vegetables. The former contain $25-$ $30 \%$ crude protein (Killinger, 1965; Wing, 1965; Kumar et al., 1985). The leaf is acceptable to cattle as silage. Kenaf seeds contain $20 \%$ edible oil (Berger, 1969), which compares favourably with cotton seed oil and can be used for making margarine and protein stock feed. The cake obtained after oil extraction can be used for compounding animal feeds, while the pulp obtained from the stems could be useful in the manufacture of paper.

Although Kenaf is potentially an important crop in Nigeria, it has largely been ignored in the genetic improvement programmes. Knowledge of the genetic variation present among Kenaf cultivars is a pre-requisite for genetic improvement. Correlations and path-coefficient analysis of traits will also help in choosing component characters in a breeding programme whose selection would result in the improvement of complex traits that are positively correlated (Aruna et al., 1989; Singh and Tuteja, 1991). The objective of this study was to investigate the extent and quality of genetic variability in a diverse population of Kenaf. The interrelationship between seed yield, an important but complex character and other yield components were also studied.

\section{MATERIALS AND METHODS}

Fifty seven Kenaf genotypes with diverse genetic backgrounds were evaluated at Samaru (Lat. $11^{\circ} 11^{\prime} \mathrm{N}$; Long. $7^{0} 38^{\prime} \mathrm{E}$; $686 \mathrm{~m}$ above sea level) in the northern Guinea Savanna of Nigeria during the rainy seasons (June-October) of 1994 and 1995. The soil type was sandy loam.

Each plot consisted of four rows, measuring $2 \mathrm{~m}$ long and $50 \mathrm{~cm}$ between stands. A randomised complete block design with three replications was used. Fertilisers were broadcasted to supply $60 \mathrm{~kg}$ $\mathrm{N}, 45 \mathrm{~kg} \mathrm{P}_{2} \mathrm{O}_{5}$ and $60 \mathrm{~kg} \mathrm{~K} 2 \mathrm{O}$ per hectare. The fertilisers were incorporated into the soil before sowing. Weeding was done once to keep the plots weed free.
Observations were recorded on plant height at flowering, butt diameter at harvest, number of capsules per plant, number of seeds per pod, 1000 seed weight and seed yield.

A combined analysis of variance was used on the data for each trait. Components of variance $\sigma^{2}{ }_{p h}, \sigma^{2}$ and $\sigma_{c}^{2}$ were obtained by setting observed mean squares to expected mean squares and solving for the desired component. Genetic coefficients of variation were calculated as $\sigma_{g}{ }^{2}$ $\sqrt{\text { mean }} \times 100$. Genetic correlation coefficients were estimated using standard variance and covariance procedures (Singh and Chaudhary, 1985; Steel et al., 1997).

The correlations obtained between the traits were further subjected to the path-coefficient analysis following the procedure outlined by Dewey and Lu (1959). This method allows the determination of direct and indirect influence of different variables on seed yield. Seed yield was considered as a resultant variable, while plant height, butt diameter, number of capsules per plant, number of seeds per pod and 1000 seed weight were the main causal variables.

\section{RESULTS AND DISCUSSION}

The estimates of the phenotypic, genotypic and environmental components of variance for the six traits are presented in Table 1, along with the genotypic coefficients of variation. Considerable variation was observed for all the traits in Kenaf population as evidenced by the values of the coefficient of variation. The values ranged from 5.90 for 1000 seed weight to 34.36 for seed yield, suggesting that there is an oppcrtunity for selection for these traits. It appears that environmental variance was relatively small. This indicates that selection for these traits will result in heritable improvement. This result conforms with those of Kumar et al. (1985) on kenaf; Khan, (1987) on mung beans; and Singh and Tuteja (1991) on ramie. There was a preponderance of genotypic components of variance for plant height, number of seeds per pod, 1000 seed weight and seed yield. These also recorded high heritability estimates of $0.51 .0 .85,0.54$ and 0.87 , respectively (Table 1 ). Thus, these traits are highly and quantitatively heritable with minimal genotype by environmental interaction. The number of capsules/plant and 
butt diameter are more influenced by genotype by environmental interaction as evidenced by their $\sigma_{\mathrm{gc}}^{2}$ and $\sigma_{\mathrm{c}}^{2}$ components. Similar results were reported by Aruna et al. (1989) in roselle and Zaria et al. (1994) in cowpea.

The genotypic correlation coefficients for the different pairs of traits are presented in Table 2. Generally, low correlations were obtained between all pairs of characters. Seed yield was positively and significantly correlated with plant height, number of seeds per pod and 1000 seed weight. Significant and positive correlations were also obtained between plant height and number of seeds per pod. These results indicate that selection for plant height, number of seeds per pod and 1000 seed weight should result in improved seed yields in Kenaf. The effectiveness of improvement in seed yield through these characters will, however, vary depending on the direct and indirect relationships with yield, their heritabilities as well as genetic control (Khan, 1987; Aruna et al., 1989; Singh and Tuteja, 1991; Zaria et al., 1994).
The causal relationship and the results of the path-coefficient analyses are presented in Table 3. The variables with the highest direct effects on seed yield were number of seeds per pod and 1000 seed weight. The direct effect of 1000 seed weight on seed yield was, however, reduced by the negative indirect effect through number of seeds per pod (Table 3 ). The path-coefficient analysis (Fig. 1) also shows negligible effects of butt diameter and number of capsules per plant on seed yield. The results suggest that in order to perform a successful breeding programme aimed at improving seed yield in Kenaf, it is necessary to pay less attention to butt diameter and number of capsules per plant when selection is practiced. Focus should be on number of seeds per pod and 1000 seed weight which are determinants of seed yield in Kenaf. Singh and Tuteja (1991), Gravois and Helms (1992), Zaria et al. (1994) and Board et al. (1997) considered seed weight, number of seed per pod and plant height as important characters in crop improvement.

TABLE 1. Components of variance and heritability for seed yield and other agronomic characters in Kenaf

\begin{tabular}{lrrrrrrr}
\hline & \multirow{2}{*}{${ }^{*} \mathrm{GCV}$} & \multicolumn{1}{c}{$\sigma^{2} \mathrm{ph}$} & \multicolumn{1}{c}{$\sigma^{2} \mathrm{~g}$} & $\sigma^{2} \mathrm{e}$ & $\sigma^{2} \mathrm{ge}$ & $\sigma^{2}$ er & $\mathrm{h}^{2}$ \\
\hline Plant height & 9.96 & 0.13 & 0.07 & 0.04 & 0.01 & 0.01 & 0.54 \\
Butt diameter & 12.48 & 0.28 & 0.08 & 0.04 & 0.02 & 0.14 & 0.29 \\
Capsules/plant & 14.63 & 109.02 & 30.32 & 25.60 & 15.03 & 38.06 & 0.28 \\
& & & & & & & \\
Seeds/pod & 25.23 & 29.78 & 23.54 & 3.72 & 2.38 & 0.24 & 0.79 \\
1000 seed weight & 5.90 & 5.09 & 2.73 & 1.02 & 0.94 & 0.40 & 0.54 \\
Seed yield & 36.36 & 9015.95 & 7855.03 & 643.40 & 389.22 & 128.30 & 0.87 \\
\hline
\end{tabular}

*GCV = genotypic coefficient of variability; $\sigma^{2}$ ph, $\sigma^{2} g, \sigma^{2}$ ge, $\sigma^{2}$ and $\sigma^{2}$ er = phenotypic, genotypic, genotype by environment, environmental and error variance, respectively

TABLE 2. Genetic correlations between seed yield and its components in kenaf

\begin{tabular}{|c|c|c|c|c|c|c|}
\hline & $\begin{array}{l}\text { Plant } \\
\text { height }\end{array}$ & $\begin{array}{c}\text { Butt } \\
\text { diameter }\end{array}$ & $\begin{array}{l}\text { Capsules } \\
\text { per pant }\end{array}$ & $\begin{array}{l}\text { Seeds } \\
\text { per pod }\end{array}$ & $\begin{array}{l}1000 \text { seed } \\
\text { weight }\end{array}$ & Seed yield \\
\hline Plant height & 1.00 & & & & & \\
\hline Butt diameter & 0.06 & 1.00 & & & & \\
\hline No. of cap. per plant & $0.36^{*}$ & 0.18 & 1.00 & & & \\
\hline No. of seeds per pod & 0.07 & -0.24 & 0.16 & 1.00 & & \\
\hline 1000 seed weight & 0.22 & 0.07 & 0.26 & $0.33^{*}$ & 1.00 & \\
\hline Seed yield & $0.31^{*}$ & -0.05 & 0.017 & $0.51^{\star \star}$ & $0.41^{*}$ & 1.00 \\
\hline
\end{tabular}

$\star, \star \star *$ Significant at $5 \%$ and $1 \%$ level of probability, respectively 
TABLE 3. Path-coefficient analysis of seed yield and its components in kenaf

\begin{tabular}{lr}
\hline Variable correlated & Path-coef \\
\hline Plant height vs. seed yield & \\
Direct effect of plant height on seed yield & 0.225 \\
Indirect effect via butt diameter & -0.020 \\
Indirect effect via number of capsules per plant & 0.013 \\
Indirect effect via number of seeds per pod & 0.039 \\
Indirect effect via 1000 seed weight & 0.051 \\
Total & 0.308
\end{tabular}

Butt diameter vs. seed yield

Direct effect of butt diameter on seed yield $\quad 0.005$

$-0.007$

Indirect effect via number of capsules per plant $\quad 0.005$

Indirect effect via number of seeds per pod $\quad-0.070$

Indirect effect via 1000 seed weight $\quad 0.018$

Total

$-0.049$

Number of capsules per plant vs. seed yield

Direct effect of number of capsules per plant on seed yield $\quad-0.051$

Indirect effect via plant height $\quad-0.041$

Indirect effect via butt diameter $\quad 0.000$

$\begin{array}{ll}\text { Indirect effect via number of seeds per pod } & 0.047\end{array}$

Indirect effect via 1000 seed weight $\quad 0.062$

Total

0.017

Number of seeds per pod vs. seed yield

Direct effect of number of seeds per pod on seed yield $\quad 0.584$

Indirect effect via plant height

Indirect effect via butt diameter $\quad-0.001$

Indirect effect via number of capsules per plant $\quad-0.004$

$\begin{array}{ll}\text { Indirect effect via } 1000 \text { seed weight } & -0.076\end{array}$

$\begin{array}{ll}\text { Total } & 0.51\end{array}$

1000 seed weight vs. seed yield

Direct effect of 1000 seed weight on seed yield $\quad 0.463$

$\begin{array}{ll}\text { Indirect effect via plant height } & 0.025\end{array}$

Indirect effect via butt diameter

Indirect effect via number of capsules per plant $\quad 0.018$

Indirect effect via No. of seeds per pod

Total

0.406

The residual effect $(\mathrm{R})$ obtained in this study (0.32), though small and positive, indicates that only $68 \%$ of the total variations in Kenaf seed yield was explained. Other factors (about 32\%) have not been considered in the present study.

In conclusion, plant height, number of seeds pod $^{-1}, 1000$ seed weight and seed yield are less influenced by the environment and its interaction. Plant height, number of seeds/pod and 1000 seed weight were found to be important yield components.

\section{REFERENCES}

Aruna, C., Subramanyam, D., Kumar, P.V.R. and Salyanarayana, G. 1989.Correlation and path analysis in Roselle (Hibiscus sabdariffa L). Journal of Research APAU 17:65-67. 


Berger, J. 1969. The worlds major fibre crops their cultivation and manuring. Center d'Etude de l'Azote, Zurich. pp. 227-231.

Board, J.E., Kang, M.S. and Harville, B.G. 1997. Path analyses identify indirect selection criteria for yield of late planted soybean. Crop Science 37:879-884.

Dewey, D.R. and Lu, K.H. 1959. A correlation and path-coefficient analysis of components of crested wheat grass seed production. Agronomy Journal 51:515-518.

Gravois, K.A. and Helms, R.S. 1992. Path analysis of rice yield and yield components as affected by seeding rate. Agronomy 84:1-4.

Khan, I.A. 1987. Path coefficient analysis of yield attributes in mutants of mung beans. TVIS News 2:15-16.

Killinger, G.B. 1965. Kenaf (Hibiscus cannabinus L.) a multi-use crop. Agronomy Journal 61:734-736.

Kumar, V., Idem, N.U.A. and Echekwu, C.A. 1985. Important components of Kenaf
(Hibiscus cannabinus L.). Proceedings of the $21^{\text {st }}$ Annual Conference of Agricultural Society of Nigeria, Ibadan, Nigeria. 20pp.

Singh, R.K. and Chaudhary, B.D. 1985. Biometrical Genetics. Kalyani Publishers, New Delhi, India. 317pp.

Singh, D.P. and Tuteja, O.P. 1991. Path coefficient analysis in ramie. Haryana Journal of Agronomy 5:70-72.

Steel, R.G.D., Torrie, J.H. and Dickey, D.A. 1997. Principles and Procedures of Statistics: A Biometrical Approach. McGaw-Hill Book Company Inc., New York, USA. 666pp.

Wing, J.M. 1965. Ensilability and Nutritional value of Kenaf. Foodstuffs 39:26-29.

Zaria, A.A., Aba, D.A. and Showemimo, F.A. 1994. Path-coefficient Analysis of grain yield in cowpea (Vigna unguiculata (L.) Walp Journal of Agriculture, Science and Technology 4:27-30. 